\title{
A Comparative Study of National and International Contracts Document refers to the FIDIC standard on Construction Projects in Indonesia
}

\author{
Dede Amar Udi Ilma ${ }^{1}$, Faqih Ma arif ${ }^{2}$, Bambang Utoyo ${ }^{3}$, Nasrun Baldah ${ }^{4}$, \\ Desy Tri Inayah ${ }^{5}$ \\ Department of International Program for Law and Sharia, Universitas Muhammadiyah Yogyakarta - \\ Indonesia ${ }^{1}$, Department of Civil Engineering, Universitas Negeri Yogyakarta ${ }^{2}$, Ministry of Education and \\ Culture $^{3}$, Department of Management, Pelita Bangsa University-Bekasi, Indonesia ${ }^{4}$, Department of \\ PKK, Sarjanawiyata Tamansiswa University-Yogyakarta ${ }^{5}$ \\ dedeamarudiilma07@gmail.com¹, faqih_maarif07@uny.ac.id², utoyo_bam@yahoo.com³, \\ nasrun.baldah@pelitabangsa.ac.id ${ }^{4}$, desytri@ustjogja.ac.id ${ }^{5}$
}

\begin{abstract}
This paper discusses the comparison between national contract standards (Presidential decree, the Minister of PUPR Regulation) and international standards that refer to FIDIC. In this study, an analysis carried out on the rights and obligations of service users and service providers, the legal aspects of contracts that refer to national and international standards (FIDIC). The method used is a literature study consists of three documents (Presidential decree, Ministry of Public Works, and FIDIC). The analysis shows that national contract standards (Presidential decree) and FIDIC international standards have similar regulations in many items. Finally, compared to the ministry of the public works contract document, the FIDIC document standard is more effective to use because the contractor has fair and balanced requirements, and accommodates the possibility of unwanted disputes in the future.
\end{abstract}

Keywords: Contract, Construction, FIDIC

\section{Introduction}

Construction Contracts are part of the applicable law in Indonesia. Indonesian binding law is arranged in book III of the Civil Code, consisting of 18 chapters and 631 articles, starting from article 1233 of the Civil Code to 1864 of the Civil Code. According to article 1233, the registered KUHPerdata every approval of the agreement or law [1].

While in book III of the Civil Code, which contains the principle of freedom in agreeing (beginsel der contractsvrijheid). This principle is taken in article 1338 of the Civil Code, which reads, "All treaties made legally, act as laws for those who make them." From the above rules, it can be concluded that the agreement is binding between the parties and gives freedom to make the agreement while not violating public order [1].

This agreement is binding (pacta sunt servanda), which means that both parties must carry out the rules contained in the contents of the agreement in good faith. In all construction project activities, it is necessary to have an agreement that has been agreed between the parties to be used as a legal basis for exercising their rights and obligations. Contracts in construction activities regulate the parties involved, prevent and protect against unwanted risks [1].

At present, Indonesia uses contract standards that refer to presidential regulations and construction services laws and other institutions such as the Department of Public Works [2], 
[3], [4]. In addition to relating to national contracts in the construction world, Indonesia also refers to international contracts, namely the FIDIC (Federation International Design Institute Conseils), which have begun to be widely used by construction actors. The selection of FIDIC is believed to be more effectively used because the contractor has fair, balanced requirements and accommodates the possibility of unwanted disputes in the future [5].

\section{Types of Contracts}

\subsection{Government Version}

Generally, each department has its standards. The standard commonly used is the Public Works Department standard. Moreover, each department has more than one standard because each Directorate General has its standards [3], [6], [7].

\subsection{National Private Version}

This version varies according to the wishes of the service user or project owner. Sometimes it quotes departmental standards, or the more advanced ones quote foreign contact systems such as FIDIC (Federation Internationale des Ingenieurs Counsels), JCT (Join Contract Tribunals), or AIA (American Institute of Architects). However, because it was taken in half measures, it is natural that this version of the contract became abysmally and very prone to disputes [8].

\subsection{Foreign Private Version}

Regularly, service users or foreign project owners use JCT or FIDIC contracts. In 1999 the FIDIC General Conditions of Contract for Construction was published as a development of the 1987 edition of the FIDIC General Conditions of Contract for Works in Civil Engineering Construction, which was amended in 1992 [9].

In 2005 it was perfected by obtaining input from several lending institutions, in the future known as the General Conditions of Contract for Construction, MDB Harmonized Edition in 2006. By publishing the model terms of the contract (conditions of contract) or commonly known as "fair and balance," FIDIC became an organization that became very popular throughout the world [10].

\subsection{Construction Contract Function}

According to [2] concerning Procurement of Government Goods / Services in article 1 paragraph 43 of the Procurement Contract of Goods / Services, hereinafter referred to as Contract, is a written agreement between the PA / KPA / PPK and the Goods / Services Provider or the executor of self-management.

The essential functions of contracts in project management are: (1) To know the rights and obligations of service providers or service users; (2) As evidence in settlement of construction disputes; (3) Providers and service users have the same purpose, in some cases contrac 
agreements that usually can be resolved by arbitration or through the court if the dispute could not be determined [2].

\section{Method}

This research was carried out through a comparative study of literature between National and International Contract Documents on FIDIC Standard Contract Requirements and conducting interviews with experts in their fields. In this paper, the researcher combines a comparative study of literature and expert judgment.

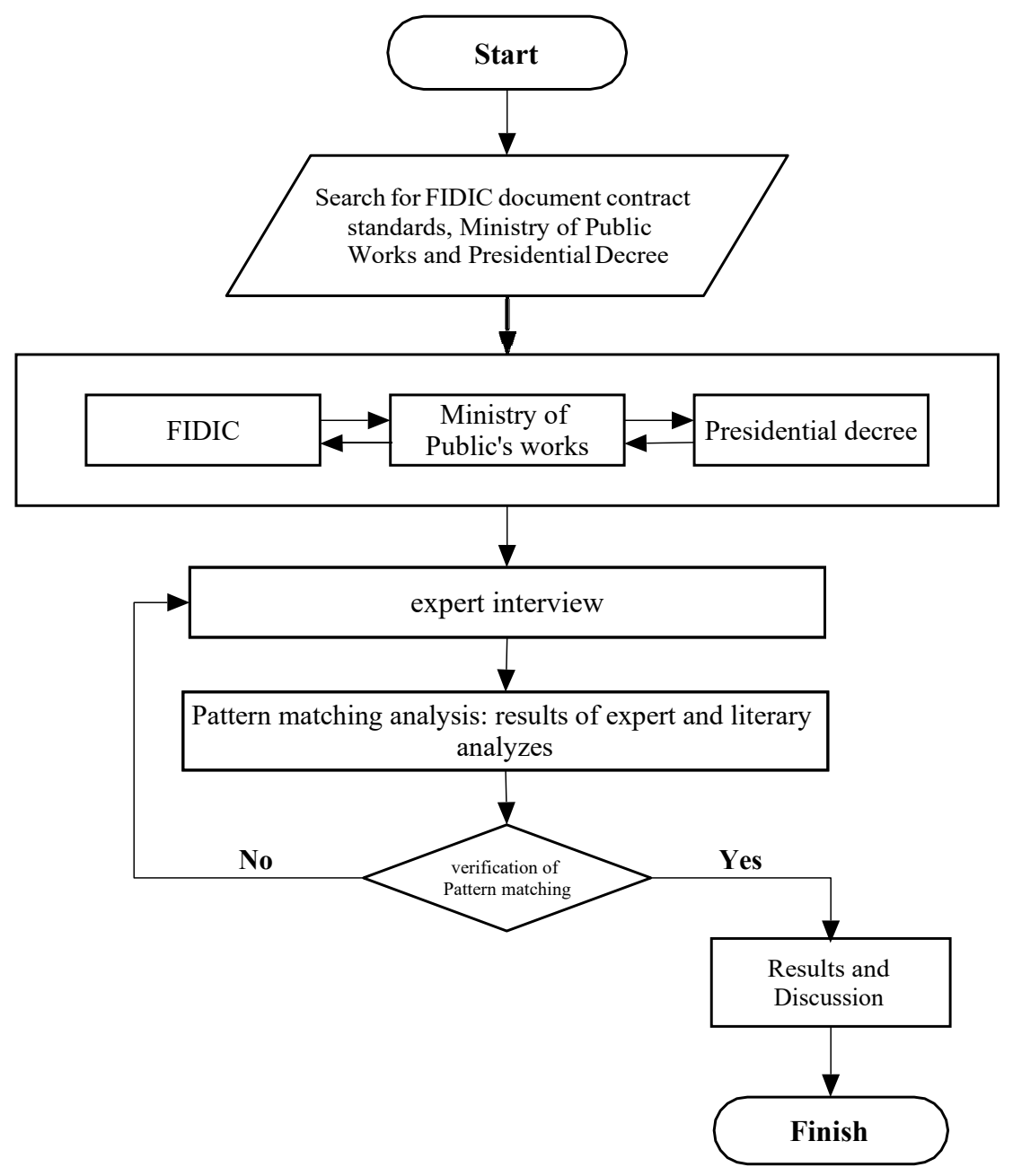

Fig. 1. Research flow chart 


\section{Results and Discussion}

\subsection{Payment Contract}

At the contract price, there are items about the agreement listed in quantity, namely: type of contract, the other role of the contractor, the third maximum amount to be paid for consulting services or construction work, and the purpose of service users. Refers to [2], it has complete items compared to the [3] and [5], the Minister of Public Works standard does not have a detailed list listed in the quantity list, whereas in [3] the role of service users and the maximum amount to be paid for construction work are not listed. When referring to the six standards, the compatibility between one standard and another is not too large [11].

Concerning imprest payment between [2], [3], [5], they do not have a significant difference. The [2] has all the required items, whereas, for the Minister of Public Works standard, the drawback lies in the service user who has to lend a down payment, in contrast to the [5], the down payment must be provided by the service user to the service provider.

Temporary payments related to contracts include the service user contractor's role, contract delays, and payment systems. In [5], only monthly or term payment systems are ignored. In [2] and [3], the contractor's failure due to non-compliance with contract and change in the minutes of payment is canceled. However, [2] still maintains the contractor's role, who must submit billing statements to service users at the end of every month and about the role of service users in verifying billing documents compared to the [5].

Final Payment is related to the completion of the work, a statement of settlement billing to service users are: Firstly, the value of all work is following the minutes. Other amounts according to which the contractor is entitled and agreed by both parties, and estimates of different numbers that will be entitled to them based on the contract. In the [5] contract item with the [3] listed minutes, especially users and service providers must sign the minutes when the work has been $100 \%$ completed, while in the FIDIC standard, this item is not listed.

However, all work's value must be following the contract [5], the agreement between the two parties, and the estimated amount according to the contractor will be satisfied. These items are not found in [2] and [3]. Secondly, the Provider must submit to the work supervisor the details of the bill value. This item is listed in the [3] while in the [2], and [5] standards are not listed.

Nevertheless, other amounts that the contractor believes are the right of them or agreed upon by both parties and service users must submit to the contractor regarding the minutes of the final payment not listed in the [3] by [12], [13]. Thirdly, Late fees in [2] and [3] are regulated regarding the amount of compensation paid by service users, whereas in the FIDIC standard, this is not determined [14]. Lastly, for retention refunds and currency of payment, only the Minister of Public Works standard does not specify the contract price to be paid in the stated currency. In the currency plan, the payment is also not explained in detail if there is a payment of more than one currency [15].

\subsection{Termination of Contract}

The termination contract is divided into several indicators, including termination by the service user, termination by the contractor, and the termination of the contract. There are several parts from item no 1 (causes of contract termination) from the subsection (a) up to (s). The FIDIC and Presidential Decree standards contain (a) The contractor fails to fulfill the implementation guarantee clause while in [3] is not declared, then on subsection (b) 
concerning neglecting the work of three standards is considered in their documents, respectively. In subsection (c) up to (e), Guarantees must have been disbursed before termination of the contract; no warning letter is required if there is a criminal verdict. The breach of the contract follows, it occurs stated in the [3], but in the Presidential Decree, standard and FIDIC items were not listed.

Afterward, from the item (f) up to (j) of the three documents [2], [3], [5], almost all listed the entire terms and conditions only in the item (h) the [5] did not mention. In comparison, [2] and [5] had included it. However, in detail (k) to item with item (r) by [3] and [2] are similar in comparison to [5]. The last item (s) showed that the termination for the convenience both (user and contractor) only listed on [2] while in [3] and [5] standards are not specified.

Finally, In item no 2 for the three contract standards, except in subsection no. 3 and 4, they are only listed on the [5] while in the [3] and [2] are not listed. However, on the contrary, in item no 5, it is precisely the [2] and [3]. This is different from items no. 6 and 7, which are only found in [3].

\subsection{Termination by Contractor}

The items from subsection (a) up to (c) that fulfill all items are only [5]. Further, in the subsection (d) up to (g), each contract standard includes them. The subsection (h) regarding service users not issuing SPP for bill payments is only listed on the [3]. Furthermore, in item (i) only [2], [3] are listed. Forward, the subsection in letter (j) all standards, including the item. In subsection no. Two up to five, the [5] contract standards are lists all of them, except for subsection no. 6 is only on the [3].

\subsection{Termination of the contract}

The Minister of Public Works standard regulates the termination of a contract if both parties agree. The rights and obligations related to payment have been fulfilled in [2], [5], while this item is not determined [16], [17].

\subsection{FIDIC Versus Ministry of Public Works}

The standard contract by [3] and [5] consists of sub-clauses regarding the right and obligations (providers and users) in construction activities [9]. FIDIC can be applied in Indonesia and does not conflict with regulations and legislation, especially in construction projects [12]. Hereinafter, each contract standard has its terms and conditions in carrying out construction project activities. It aims to create an orderly implementation of construction services that guarantee equality of position between providers and users in exercising their rights and obligations.

The terms and conditions of this contract should be following [7] article 47 paragraph 1 (Construction Work Contracts), which states that the construction work contract at least includes a description of [7]. Firstly, Work formulation contains a clear and detailed description of the work scope, work value, unit price, lump sum, and time limits for implementation. Secondly, equality of rights and obligations of service is providers and users. Thirdly, termination of construction work contract; Lastly, Guarantees and responsibilities in law dealt with a construction failure. Based on the results of a comparison between FIDIC and the Minister of Public Works, it can be concluded that FIDIC does not conflict with the laws in force in Indonesia. Overall, the FIDIC Contract standard is still better compared with the contractual 
standards of the Minister of Public Works. It can be seen in the comparison in several subclauses of the Minister of Public Works are not in the standard FIDIC contract even though the sub-clauses are very important [6], [7].

\subsection{FIDIC Versus Presidential Decree}

Both contract standards state users and service providers' rights and obligations in carrying out construction activities [18]. In terms of payment indicators, both contract standards have their criteria. In [5], if the work carried out by the contractor fails and is not following the contract, the cost of repairs or replacements can be withheld until the repair or replacement is complete [19].

Whereas in the Presidential decree, on the contrary, when the work carried out by the contractor fails and does not comply with the contract, the cost of repair or replacement cannot be withheld. Although there are some differences in the payment indicators, the two contract standards have many similarities in the termination indicator.

Further, the analysis shows that in [2] and [5] has almost similar suitability refer to subclauses. In general, FIDIC has clear and detailed regulatory criteria. It is one reason why the FIDIC contract standard is still a reference for construction project activities in the world.

\subsection{Expert Judgment}

Based on the three contracts standard document [2], [3], [5], FIDIC has complete regulation compare with [2] and [3]. In this case, LKPP has also summarized the interests of many parties in implementing goods and services regulations, including FIDIC. In LKPP, insurance can be used because of the private sector's insistence, and the cost is cheaper, while the loan regulation necessity is with a commercial bank.

Furthermore, FIDIC also accommodates the [2] and [3] contract standards. In [5], if the first party fails to pay for the second party, there will be sanctions. This regulation has been specified in [2] and [3], although, in reality, it is difficult to implement.

Finally, in [3] based on request government as backing up the regulation is semiindependent, because they still have to adjust government regulations (LKPP). LKPP summarizes many parties' interests in the implementation of the goods and services, for example, at LKPP, it can use insurance because of private insistence because the cost is cheaper. In contrast, loan regulations must be with commercial banks.

\section{Conclusion}

Based on the results of the analysis discussion above, it can be concluded that the FIDIC document is complete and effective than [2] and [3]. It is because of the scope in line with the construction project's objectives compared to the [2] and [3]. The FIDIC contract standard further guarantees equal rights and obligations of service providers and service users. It is why the name FIDIC is known as "fair and balanced" [20]. There are several essential sub-clauses contained in FIDIC, but they are not listed in the two documents. In contrast, if a document is incomplete in contents, it will be difficult to resolve disputes between service providers and service users because the material is referred to [21]. 


\section{References}

[1] Kitab Undang - Undang Hukum Perdata (KUHPer) buku III tentang perikatan. (In Indonesian)

[2] Peraturan Presiden Nomor 16 Tahun 2018 Tentang Pengadaan Barang/Jasa Pemerintah. (In Indonesian).

[3] Peraturan Menteri PUPR Nomor 14 tahun 2020 Tentang Standar Dan Pedoman Pengadaan Jasa Kontruksi Melalui Penyedia. (In Indonesian).

[4] PP No.29 tahun 2000 Tentang Penyelenggaraan Jasa Konstruksi. (In Indonesian).

[5] Apostolov, I.: Revenue Recognition from Construction Contracts: Differences between Bulgarian National accounting standards and International accounting standars. Procedia Economics and Finance. pp. 1647-1653 (2015).

[6] PP No.29/2000 Tentang Penyelenggaraan Jasa Konstruksi; (In Indonesian).

[7] UU No. 18 Tahun 1999 \& UU No. 2 Tahun 2017 Tentang Jasa Kontruksi. (In Indonesian).

[8] Wibisono, A., Hardjomulyadi, S.: Analysis of the FIDIC Rainbow Contract Model Selection 2017 2017 Jetty Construction Project. Konstruksia. pp. 15-24 (2018).

[9] Goh, M., \& Goh, Y. M.: Lean Production Theory-Based Simulation of Modular Construction Processes. Automation in Construction. pp. 227-244 (2019).

[10] Brome, J. C., Hayes, R. W.: A Comparison of the Clarity of Traditional Construction Contracts and of the New Engineering Contract. International Journal of Project Management. pp. 255-261 (1997).

[11] Ramli, S.: Harga yang Diperjanjikan Dalam Kontrak. Book (2017) (In Indonesian)

[12] Marzouk, M. M., et al.: Factors Influencing Sub-Contractors Selection in Construction Projects. Housing and Building National Research Center, 9(2). pp. 150-158 (2013).

[13] PP No. 30 - 2000: Tentang Penyelenggaraan Pembinaan Jasa Konstruksi; (In Indonesian).

[14] PP No 4/2010: tentang perubahan atas PP No.28/2000 Tentang Usaha Dan Peran Masyarakat Jasa Konstruksi. (In Indonesian).

[15] PP No.92/2010 : Tentang Perubahan Kedua atas PP No.28/2000 Tentang Usaha dan Peran Masyarakat Jasa Kontruksi. (In Indonesian).

[16] Yang, Z.: The Study on Law Disputes in Construction Project Contract Relationship. Physics Procedia. pp. (2012).

[17] Liu, J., Li, H., Skitmore, M., Zhang, Y.: Experience Mining Based on Case-Based Reasoning for Dispute Settlement Of International Construction Projects. Automation in Construction. pp. 181191 (2019).

[18] Gao, R., et al.: Investigating the Difficulties of Implementing Safety Practice in International Construction Projects. Safety Science. pp. 39-47 (2018).

[19] You, J., et al.,: Opportunistic Behavior, and Governance in Construction Projects: The efficacy of contracts. International Journal of Project Management. pp. 1-13. (2018).

[20] Negrut, M. L., Luminosu, C., Mihartescu, A. A.: Considerations on the Approach of the Contractual Agremeent for Construction Works. Procedia Social and Behavioral Sciences. pp. 514- 520. (2014).

[21] Purnus, A., \& Bodea, C. N.: Multi-Criteria Cash Flow Analysis in Construction Projects. Creative Construction Conference. pp. 98-105 (2016). 